\title{
LINGKARAN MAKNA AKUNTANSI BUKAN SEBATAS ANGKA
}

\author{
Layly Dwi Rohmatunnisa \\ Institut Teknologi dan Bisnis Asia Malang \\ Email : r.laylydwi@gmail.com
}

\begin{abstract}
The purpose of this study is to find and describe the meaning of accounting in the perspective of Ethnic Chinese. This research focuses on the Chinese ethnic who has a business in the Malang City or Regency area which is engaged in animal husbandry. The data for this study were collected through observation, interviews and documentation images. This research was conducted qualitatively, phenomenology as a method and an analytical tool and the unit of analysis focused on the mind, self and society of the object being analyzed. The meaning of accounting is really interesting from the perspective of Ethnic Chinese, because they are doing a complete report on their business which is considered as accounting. The results of this study indicate that in their business activities the accounting ethnic Chinese entrepreneurs are measured by; (1) accounting as information, (2) accounting as calculation (based on decisions), and (3) accounting as responsibility.

Keywords: Meaning of accounting, Ethnicity, MSME
\end{abstract}

\begin{abstract}
ABSTRAK
Tujuan dari penelitian ini adalah untuk menemukan dan mendeskripsikan makna akuntansi dalam cara pandang Etnis Tionghoa. Penelitian ini berfokus pada Etnis Tionghoa yang memiliki usaha di wilayang Kota atau Kabupaten Malang yang bergerak dalam bidang peternakan. Data untuk penelitian ini dikumpulkan melalui observasi, wawancara dan gambar dokumentasi. Penelitian ini dilakukan secara kualitatif, fenomenologi sebagai metode dan alat analisis dan unit analisis berfokus pada pikiran, diri dan masyarakat objek yang dianalisis. Arti akuntansi benar-benar menarik dari perspektif Etnis Tionghoa, karena mereka sedang melakukan laporan lengkap tentang bisnis mereka yang dianggap sebagai akuntansi. Hasil penelitian ini menunjukkan bahwa dalam aktivitas bisnisnya para pengusaha Etnis Tionghoa akuntansi yang diukur dengan cara; (1) akuntansi sebagai informasi, (2) akuntansi sebagai perhitungan (berdasarkan keputusan), dan (3) akuntansi sebagai tanggung jawab.

Kata Kunci: Makna akuntansi, Etnis, UMKM
\end{abstract}

\section{PENDAHULUAN}

Banyak peneliti yang beranggapan bahwa akuntansi hanyalah milik perusahaan besar, dimana perusahaan tersebut menggunakan laporan keuangan guna menarik investor untuk menanamkan dana di perusahaan bersangkutan. Selain itu, beberapa peneliti beranggapan bahwa sebagian besar dari pengusaha kecil dan menengah masih belum mengerti pencatatan akuntansi bahkan tidak memiliki catatan keuangan. Padahal jika ditelusuri lebih dalam akuntansi juga terdapat pada pengusaha kecil dan menenggah. Hanya saja berbeda cara pengemasan akuntasi yang dilakukan pengusaha kecil dan menengah salama ini. Akuntansi bagi pengusaha kecil dan menenggah tidak perlu ribet asalkan pembukuan tepat dan tidak selisih antara pemasukkan dan pengeluaran.

Perbicara terkait perusahaan besar di Indonesia percaya atau tidak sebagian besar didomonasi oleh etnis Tioghoa. Etnis Tionghoa merupakan salah satu etnis yang merantau ke luar negeri. Berawal dari faktor ekonomi dan meningkatnya jumlah penduduk menyebabkan 
lapangan pekerjaan menjadi semakin sempit. Oleh karena itu, mereka merantau ke beberapa negara yang salah satunya ke Indonesia untuk mendapatkan peruntungan yang baik. Etnis Tionghoa di Indonesia masuk ke dalam daftar 20 etnis terbesar di Indonesia. Berdasarkan data sensus penduduk tahun 2010, jumlah keturunan Tionghoa di Indonesia mencapai 2,83 juta jiwa atau sekitar 1,2\% dari total penduduk Indonesia yang berjumlah 236,73 juta jiwa. Dengan jumlah tersebut warga keturunan Tionghoa berada di urutan 18 berdasarkan suku bangsa yang ada di Indonesia. Sedari kecil etnis Tionghoa telah memiliki mindset dan jiwa enterpreneurship yang mana mereka tidak malu ketika usia masih kecil harus bekerja. Selain itu, menurut mereka pekerjaan sebagai pebisnis atau pengusaha merupakan pekerjaan yang sangat terhormat dan membanggakan (Guang:44).

Berkaitan dengan dua pemikiran peneliti yang pertama tentang usaha kecil dan menengah merupakan hal yang mengelitik untuk ditelusuri dan kedua, minoritas etnis Tionghoa dapat menjadi salah satu putaran besar perekonomian di Indonesia. Maka dari itu, peneliti tertarik untuk melakukan penelitian di pengusaha Etnis Tionghoa dimana dengan skala yang tidak terlalu besar. Peneliti mengartikan skala tidak terlalu besar yaitu dengan melihat pelaporan keuangan perusahan yang masih sederhana dan tidak dipergunakan untuk kepentingan investor. Hal lain yang mengusik pikiran peneliti adalah sebuah peribahasa lama "belajarlah samapai ke Negeri Cina/ Tiongkok", kutipan tersebut membuat peneliti bertanyatanya jika dikaitkan dengan akuntansi dan atau pengelolaan keuangan usaha etnis Tionghoa apakah peribahasa itu juga berlaku? Seolah-oleh kita maysarakat Indonesia harus berkaca kepada cara pandang etis Tionghoa dalam mengerakan perekonomian. Hal ini juga yang membuat peneliti merasa lebih tertantang hal besar apa yang tersipan di dalam setiap pengusahaan etnis Tionghoa?

Bagaimana etnis Tionghoa memandang akuntansi yang menyatu dalam bisnis mereka menjadi topik hangat penelitian ini. Bagaimana etnis Tionghoa dengan skala kecil dan menengah dapat bertahan dan terus bekembang di Nusantara? Akuntansi seperti apa yang mereka gunakan dalam bisnis mereka yang masih skala kecil dan menengah. Hal ini yang akan peneliti kupas dalam penelitian ini. Beberapa penelitian terdahulu yang relevan dan berkaitan dengan penelitian yang akan dilakukan oleh penelitian ini. Berikut merupakan penelitian terdahulu yang berkaitan dengan penelitian yang akan dilakukan: Penelitian yang dilakukan oleh Jacobs (2002) menunjukkan kehadiran akuntansi bermakna bahwa akuntansi digunakan dalam kegiatan bisnis sehari-hari mereka namun belum menerapkan bentuk akuntansi secara formal karena hanya digunakan oleh pihak pengelola usaha. Selain itu, adanya ketidaktahuan literasi pemilik UMKM yang menyebabkan akuntansi tidak diterapkan secara formal. Usaha dari ketiga pelaku usaha dapat terus berkembang dan tumbuh meskipun akuntansi tidak diterapkan secara maksimal dalam kegiatan bisnis mereka.

Penelitian dilakukan oleh Kurniawati (2012) menunjukkan bahwa sebagian besar pengusaha tidak mengetahui laba yang didapatkan, mereka menjawab bukan dengan nominal angka rupiah melainkan dengan benda-benda berwujud seperti motor, rumah atau mobil. Hasil penelitian yaitu bahwa masih kurangnya pemahaman akuntansi dikarenakan dari latar belakang pendidikan yang kurang memadai, belum pernah mengikuti pelatihan akuntansi dan kebutuhan akuntansi masih kurang memadai dan dari segi pengelola belum ada kebutuhan terhadap penerapan akuntansi. 
Penelitian yang dilakukan oleh Suwanto (2016) menujukkan bahwa pengusaha kecil memandang bahwa proses akuntansi dianggap membuang waktu dan juga biaya. Berdasarkan hasil penelitiannya bahwa akuntansi dimaknai sebagai informasi. Para pelaku usaha dapat mengetahui berapa besaran atau proporsi yang di dapatkan melalui kegiatan pencatatan yang dilakukan. Akuntansi sebagai pertanggungjawaban yang dapat dijadikan tolak ukur oleh pedagang untuk menentukan besaran kewajiban yang harus disetorkan kepada pemilik usaha. Akuntansi sebagai perhitungan (dasar pengambilan keputusan). Dimana tanpa disadari walaupun sebagaian besar usaha tidak melakukan akuntansi yang sesuai, nyatanya mereka memahami kegiatan tersebut dengan makna yang berbeda.

Penelitian yang dilakukan Zuhdi (2011) makna informasi akuntansi sebagai dasar pengambilan keputusan bisnis UKM. Penelitian ini menggunakan pendeketan fenomenologi dimana memaknai proses pencatatan akuntansi dalam suatu usaha UKM itu diperlukan. Perlu adanya dukungan dengan membuat laporan keuangan suatu usaha yang sedang dijalankan.

\section{METODE PENELITIAN}

Pendekatan yang dilakukan dalam penelitian ini adalah pendekatan kualitatif. Jenis penelitian yang digunakan dalam penelitian ini adalah fenomenologi. Fenomenologi memandang bahwa perilaku tiap individu, baik segala sesuatu yang dilakukan maupun dikatakan merupakan hasil dari penafsirannya atas dunia (Sobur: 2013). Fenomenologi bertujuan untuk mengetahui bagaimana kita menginterpretasikan tindakan sosial kita dan orang lain sebagai sebuah bermakna (dimaknai) dan untuk merekonstruksi kembali turunan makna (makna yang digunakan saat berikutnya) dari tindakan yang bermakna pada komunikasi intersubjektif individu dalam kehidupan sosial.

Kehadiran peneliti dalam penelitian ini adalah sebagai instrument utama dalam melakukan pengumpulan data dengan melakukan interaksi secara langsung dengan informan. Oleh karena itu terdapat beberapa sikap peneliti yang harus dilakukan agar kehadiran dari peneliti tetap menjaga sifat alami suatu penelitian kualitatif. Sikap peneliti yang dimaksudkan adalah sikap berupa adaptif, responsif, expansif, mengklarifikasi, dan meningkatkan kemampuan peneliti dalam mengumpulkan data.

Penelitian dilakukan pada dua lokasi yang mana lokasi tersebut merupakan usaha yang bergerak dalam bidang peternakan. Peneliti tidak dapat memberikan informasi terkait lokasi penelitian secara gambling karena pihak nara sumber tidak berkenan untuk dicantumkan dalam hasil penelitian.

\section{HASIL DAN PEMBAHASAN Informasi}

Peneliti menemukan bahwasannya pencatatan yang dilakukan oleh pengusaha Tionghoa memiliki peran yang penting. Dari pencatatan tersebut para pengusaha Tionghoa dapat memperoleh informasi yang dibutuhkan. Pengusaha Tionghoa menyadari bahwa dalam menjalankan kegiatan usaha perlu dilakukan pencatatan agar nantinya dapat menghidari hal yang tidak diinginkan. Pengusaha Tionghoa beranggapan bahwa pencatatan yang dibuat dapat bermanfaat untuk dirinya, dengan melakukan pencatatan pemilik usaha akan mendapatkan 
informasi yang diinginkan dan nantinya akan dikonsumsikan kepada lingkungan (sosial). Lingkungan yang dimaksud disiniadalah para investor yang nantinya mungkin akan melakukan kerja sama.

Kegiatan pencatatan yang dalam hal ini disebut sebagai akuntansi dianggap sebagai informasi yang akan menjadi dasar dalam berlangsungnya kegiatan usaha. Adapun informasi yang diperoleh, mencakup informasi jumlah penjualan/ pemasukkan dan pengeluaran biayabiaya dalam proses usaha. Selain itu kegiatan pencatatan juga memberikan informasi berupa jumlah barang yang sudah terjual dan yang menjadi stock di gudang, informasi terkait produk yang paling diminati oleh konsumen (di lihat dari barang yang sering habis terjual). Dari pencatatan juga dapat diketahui supplier yang kinerja baik dan tidak. Dan yang paling penting pencatatan dapat memberikan informasi pagi pemilik untuk melihat posisi bisnis saat ini, apakah dalam kondisi baik atau tidak, menurun atau meningkat. Sehingga, dari pencatatan tersebut dapat digunakan sebagai pengambilan keputusan oleh pemilik.

\section{Perhitungan}

Pencatatan yang dilakukan oleh pengusaha Tionghoa sekalu informan dapat dikatakan cukup sederhana dan tidak seperti laporan keuangan yang konkrit, pencatatan yang dibuat oleh informan dianggap dapat menjadi gambaran dalam mengambil keputusan oleh pemilik usaha. Dari pencatatan yang sederhana ini sudah tampak menawakili dan dapat mengetahui keseluruhan modal usaha, kemudian dapat dipertimbangkan unsur laba/ rugi yang dihasilkan dari proses bsinis. Peneliti juga menemukan dari hasil catatan perhitungan pengusaha Tionghoa, menggambarkan naik/ turunnya produk dipasaran. Dapat dilihat dari permintaan ekan kerja yang mengambil produk di usaha Tionghoa. Jika permintaan tinggi berarti minat pasar tinggi jika rendah dan jangkawaktu penagmbilan barang kembali lama maka, minat pasar rendah. Namun pengusaha Tionghoa akan selalu melihat kemnali trade record rekan kerja melalui pencatatan yang selalu di buat, terkait kenerja rekan kerja. Untukmentukan apakah harus diberikan produk yang banyak atau kurang dibandingan yang lain.

Peneliti dapat menyatakan jika perhitungan ini dilakukan ketika pengusaha Tionghoa sudah mendapatkan informasi akuntansi terkait proses bisnis. Sehingga dari perolehan informasi tersebut nantinya akan dilakukan pencatatan berupa perhitungan yang dapat dijadikan sebagai pengambilan keputusan oleh pemilik.

\section{Tanggung Jawab}

Berdasarkan penelitian yang peneliti lakukan, peneliti menemukan bahwa dalam menjalankan kegiata usaha, pencatatan informasi menjadi patokan atau dasar perhitungan pengusaha Tioghoa, yang dapat diguanakan segai perantara untuk tercapainya tujuan-tujuan perusahaan. Selain itu sumber daya manusia harus baik, dengan seumber daya manusia yang baik nantinya tujuan-tujuan perusahaan akan lebih mudah untuk dicapai. Peneliti mengatakan sumber daya manuasia yang baik karena selama peneliti melakukan pengamatan peneliti melihat bahwa dalam menjalankan usaha semua karyawan dan rekan kerja harus memiliki tanggung jawab kepada pemilik. Kepercayaan yang diberikan pemilik mewajibkan setiap karyawan harus mempertangungjawabkan setiap hal terkait usaha. Sehingga, dalam hal ini 
menuntut semberdaya manusia yang baik yang selalu dapat mempertanggungjawabkan setiap proses bisnis yang sudah dipercayakan oleh pemilik.

Pentingnya pelaporan pertanggungjawaban ini karena ini merupakan sebuah proses penentu bagaimana pemilik harus mengambil keputusan agar usaha semakin berkembang dan mengalami kemajuan. Dari laporan pertanggungjawaban kepada pemilik ini juga nantinya akan menjadi informasi awal perhitungan dalam perusahaan. Peneliti dapat mengatakan jika informasi awal nantinya akan mengahsilkan sebuah perhitungan dan dari perhtiungn tersebut akan memunculakn laporan pertanggungjawaban dan dari laporan pertanggungjawaban akan diperoleh sebuh informasi awal, dan begitu seterusnya.

\section{Laingkaran Makna Akuntansi}

Peneliti menemukan lingkaran makna akuntansi dalam bisnis etnis Tionghoa. Tiga unsur makna akuntnasi yang tersirat dalam bisnis etnis Tionghoa dapat digamabrkan dalam diagram di bawah ini:

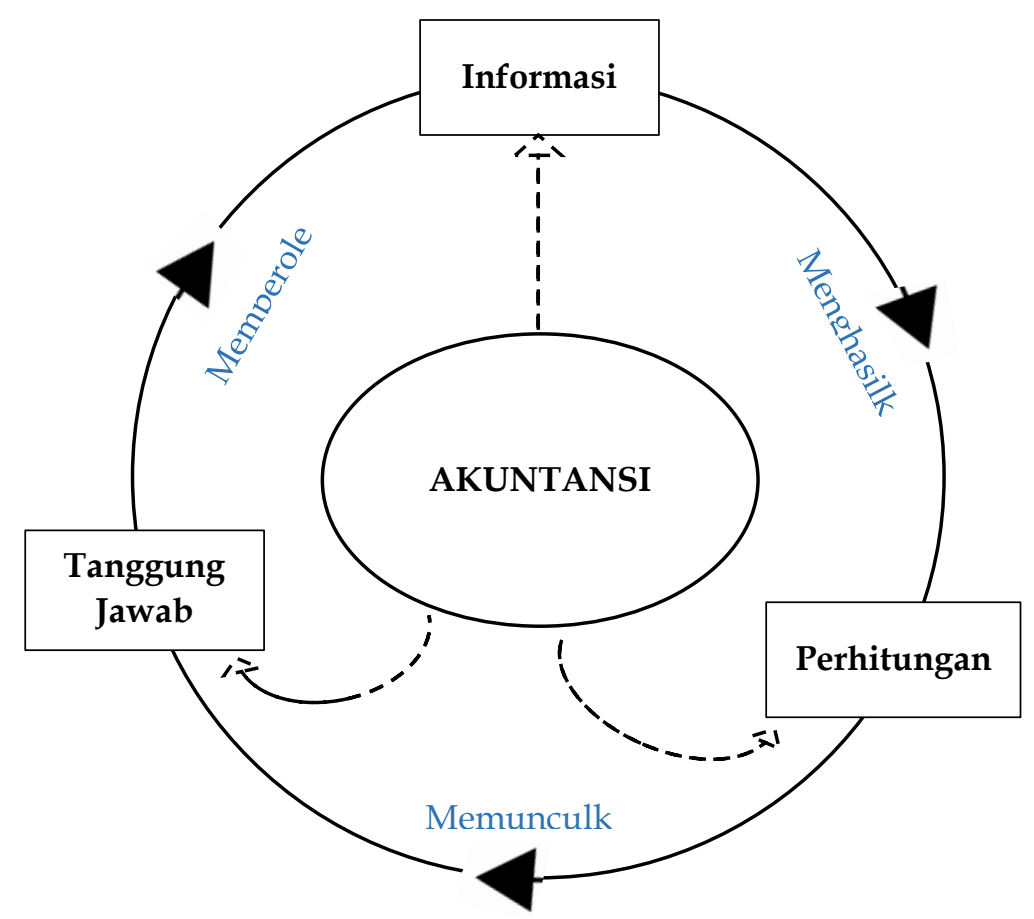

Diagram 1 Lingkaran Makan Akuntansi

Dari diagram di atas terlihat tiga unsur makan akuntansi yang pertama informasi, kedua perhitungan, dan ketiga tanggung jawab. Diagram diatas menjelaskan makna akuntansi etnis Tioghoa bahwa akuntansi sebagai informasi, diamana informasi tersebut yang nantinya akan menghasilkan bahan perhitungan dan dari perhtiungan tersebut akan diolah yang akhirnya digunakan oleh pemilik sebagai salah satu alat pengambil keputusan dalam bisnis orang Tionghoa. Dari hasil perhitungan tersebut akan memunculkan sebuah pertanggungjawaban yang diserahkan dari bagian keuangan kepada pemilik bisnis. 
Peneliti menemukan tiga unsur makan aktuntanis tersebut berdasarkan dari hasil pengamatan yang dilakukan pada dua tempat penelitian, dimana semua tempat tersebut merupakan milik dari orang Tionghoa yang bergerak dalam bisnis peternakan. Sehingga untuk mengambil kesimpulan atas makna akuntansi memiliki sudut pandang yang tidak terlalu jauh. Hal itu dikarenakan orang Tinghoa selaku informan memiliki lata belakang dan bidang bisnis yang sama. Hal tersebut pula lah yang mempermudah peneliti dalam menemukan makna akuntansi atas sudut pandang etnis Tionghoa.

\section{SIMPULAN, KETERBATASAN, DAN SARAN}

Berdasarkan pengamatan yang telah dilakukan oleh peneliti, sehingga penelitian ini menghasilkan kesimpulan:

1. Akuntansi dimaknai sebagai informasi, pengusaha Tionghoa dapat mengetahui berapa pemasukan dan pengeluaran dalam periode tertentu.

2. Akuntansi sebagai perhitungan yaitu, yang digunakan sebagai dasar pengambilan keputusan bagi pengusaha Tionghoa untuk perputaran bisnisnya.

3. Akuntansi sebagai pertanggungjawaban, ini mengambarkan proses pertanggungjawaban bagain keuangan kepada pemilik bisnis Tionghoa.

4. Adapun keterbatasan pada penelitian ini diantaranya (1) keterbatasan waktu yang dimiliki oleh peneliti dalam melakukan pengamtan sehingga ada beberapa peristwa yang terlewatkan. (2) Jadwal informan yang cukup padat sehingga peneliti kesulitan dalam membuat pertemuan dengan informan.

5. Terlepas dari keterbatasan yang ada, implikasi dari penelitian untuk menunjang penelitian selanjutnya agar lebih baik, yaitu: pertama, makna akuntansi perlu digali melalui beberapa pandangan lain yang lebih luas dan waktu penelitian yang lebih panjang. Kedua, pentingnya melakukan pendekatan dengan informan agar data yang ditemukan dapat lebih mendalam dan menghasilkan temuan yang tidak bias. Ketiga, dalam pnelitian selanjutnya langkat lebih baik jika tidak hanya berfokus pada makna kauntansi etnis Tionghoa dalam bidang peternakan, perlu juga dilakukan dari sudut pandang etnis lain dengan bidang bisnis yang berbeda pula.

Penelitian ini hanya sebatas pada makna akuntansi pada perspektif pengusaha Tioghoa tidak menyeluruh pada semua lingkup pengusaha. Sehingga, makna akuntansi yang di ambil hanya sebatas pendapat dari salah satu pengusaha Tionghoa. Peneliti selanjutnya bisa mengambil makna akuntansi dari berbagai aspek usaha dan etnis yang ada di Indonesia

\section{DAFTAR PUSTAKA}

Guang, L. S. (2009). Rahasia Kaya dan Sukses Pebisnis Tionghoa. Andi.

Sobur, A. \& Nita, N. M. (2013). Filsafat Kominukasi, Tradisi, dan Metode Fenomenologi. PT. Remaja.

Jacobs, K.J. (2002). Exploring Accounting Presence And Absen: Case studies From Bangladesh. Accounting, Auditing, and Accountability Journal, 15, 2, 143-161.

Kurniawati, E.P., Nugroho, P.I., \& Arifin, C. (2012). Penerapan Akuntansi pada Usaha Kecil, Mikro, dan Menengah (UMKM). Jurnal Manajemen dan Keuangan, 10, 2. 
Suwanto, W.L., Niswatin., Rosuli, L.O. (2016). Makna Akuntansi dalam Perspektif Pedagang Bakso "Arema” Perantauan di Kota Gorontalo. Jurnal Akuntansi Aktual, 3, 4, 282 289.

Zuhdi, R. (2011). Makna informasi akuntansi sebagai dasar pengambilan keputusan bisnis usaha kecil dan mikro (UKM) . Jurnal Akuntansi Multiparadigma, 2, 3. 